\title{
Exploring the Effect of Electronic Banking Services on the Satisfaction Level of Maskan Bank's Customers Using the Kano Model: A Case Study of the Customers of Maskan Bank Branches in Mashhad
}

\author{
Dr Naushadul Haque Mullick \\ Professor, Center Management Studies, \\ Jamia Millia Islamia University, New Delhi, India \\ nmullick@jmi.ac.in \\ Mohammad Kafi \\ Ph.D Student of Marketing, Faculty Management, \\ Jamia Millia Islamia, New Delhi, India \\ kafimohammad79@yahoo.com
}

\begin{abstract}
Nowadays, competition for increasing the quality of electronic banking services is a key issue for organizations which are active in the service industry. Organizations that reach a higher level of service quality would achieve a higher level of customer satisfaction. All organizations aim at customer attraction and higher customer satisfaction. This issue becomes more important in the case of banks which are in constant relationship with the customers. Moreover, there exists an increasing competition among banks and credit institutes for absorbing monetary resources. Therefore, creating competitive advantage seems to be a necessary issue for the survival of banks. New approaches in providing electronic banking services which have a close relationship with information and communication technology are among the most important factors in creating competitive advantage for banks, attracting customers and satisfying them. In the current study which uses the qualitative method of data collection, the researcher evaluated the effect of providing electronic banking services on the satisfaction level of Maskan Bank's customers using the Kano model through a comprehensive review of the related literature and receiving the viewpoints of experts in the field. In addition, the most and least effective factors on this satisfaction are categorized and identified. The maximum number of sample population was determined to be 384 through Morgan table. After distributing the questionnaire, a total of 384 completed questionnaires were received and analyzed. According to the results obtained from the Wilcoxon signed-rank test, the main hypothesis of this study regarding the positive effect of providing electronic banking services on customer satisfaction was confirmed. Also, the results confirmed the sub-ordinate hypotheses regarding the effect of the motivational, emotional, and functional factors of electronic banking services on increasing the level of customer satisfaction.
\end{abstract}

Keywords: "Customer satisfaction", "electronic banking", "Maskan Bank"

\section{Introduction:}

Today, one of the essential tools for expanding electronic commerce is the existence of an electronic banking system that facilitates electronic commerce activities along with global financial and monetary systems. In recent years, the use of e-banking capabilities by customers has welcomed increasingly, that one of the reasons is the easy usage of e-banking systems and the reduced cost of receiving services. Cutler, on the other hand, believes that 79 percent of all practitioners are employed in services section and the reflection of these changes emphasizes that service marketing has changed into an important field for scientific research. Banking and financial services are an important part of the industry (Myshkin, 2001), and the quality of these services is closely related to customer satisfaction in the banking industry (Avokiran, 1994). The development of e-banking has led to the acceleration of financial transactions by removing geographical and time constraints. In the words of Hirst, the global theorist, "E-banking will soon become an aggressive working policy, not a force resulted from Passivity", this means that all businesses will be affected by e-banking and not just e-banking will effect on them (Abbasi Nejad \& Mehrnoosh, 2010). Therefore, considering the importance of the purpose of this study is to investigate the impact of providing electronic banking services on customer satisfaction of Maskan Bank. 


\section{Statement of the problem:}

The service industry is changing all over the world today. New technologies have changed the way of providing service for customers in many service organizations. It can be said, one of the most powerful forces for creating a change in today's competitive environment is telecommunications and information technology. The extent of transactions through internet is increasing day by day and organizations that do not use this technology will disappear in a short time. One of the most basic applications of information technology is in the service sectors such as e-banking, insurance, e-marketing, e-commerce and so on. As the international economy develops and markets become more competitive, banks are affected and the banking industry is rapidly changing (Vankatsh \& Davis, 2000). Also, as an important pillar of economic structures and financial systems, banks must be in the line of new developments, as well as being a source of newer developments. Today, the world's major banks have increased competition in the banking industry through electronic channels and the development of their electronic services (Seyed Javadin \& Yazdani, 2005). The rise and improvement of electronic banking services around the world has led to breaking boundaries and constraints. E-banking is a self-service approach that can provide better customer service and speed up transactions and presented services in banks. On the other hand, a part of the bank work staffs is involved in setting up, developing or deploying new information systems. Therefore, it is essential to understand the attitude of the clients towards the acceptance level and use of banks' electronic services. Therefore, success in the field of e-banking requires the acceptance and use of these services by customers. The main problem that the bank is currently facing is the lack of sufficient information and awareness of the clients about the new services offered by the bank. In Iran, despite the development of electronic services and the development of internet infrastructures, we still see frequent reference to banks. On the other hand, bank is a customer-based organization that must attract the customers and try to increase the satisfaction and preservation of customers, through utilization of marketing, because the customer is the bank's main capital, and without the customer bank is meaningless. What is important to a person when refers to an organization or a company is meeting his expectations and the more the expectations are met, the more satisfied he is with the organization. In fact, the customer satisfaction is the essence of success in today's business world. Therefore, customer satisfaction is an incentive to reuse the services provided.

So, according to aforementioned, banks are eager to provide electronic services, improve banking operations, reduce costs and thereby increase profitability, remove time and space constraints, expand banking and marketing, speed up providing bank services, increasing satisfaction and ultimately loyalty to customers justifies the need to conduct a research in this field. Customers' acceptance and use of e-banking services and their willingness to reuse these systems is directly related to their perception of considerable service characteristics. Therefore, this study will investigate the impact of providing e-banking services on customer satisfaction of Maskan Bank using Kano model (Case study of Mashhad Maskan Banks' customers).

\section{Subject matter:}

The credibility of a successful organization is based on that organization's long-term relationships with customers, and the most important factor of customer satisfaction and loyalty is providing the right services. Customer satisfaction determines the success or failure of any organization. So knowing how customers are satisfied has an especial importance. The degree of customer satisfaction, in addition to showing how successful the organization is in achieving some of its goals, enables the supplier organizations to modify and improve the quality and methods. On the other hand, customer satisfaction has its benefits such as creating competitive advantages, encouraging customers to repeat the transaction and loyalty, reducing the costs of attracting new customers, increasing reputation and credibility, reducing the costs driven from mistakes and as well as sustainable growth and development. Taking into account the above mentioned, meeting the needs and ultimately customer satisfaction and understanding him by service organizations such as banks is an important and vital task. A bank satisfied customer not only reuses the services offered by the bank, but also by defining these products to others attracts new customers. The banks that can't keep customers satisfied for a long time will be out of the competition. Providing high quality service and at a high level, continually creates a competitive advantage for the bank.

The findings show that more than $90 \%$ of dissatisfied customers of a company do not try to communicate with the organization in order to state a complaint or criticism. These clients refer to rivals to meet their needs and express their dissatisfaction with all other potential customers (Fathiyan \& Shafia, 2009). Numerous studies also show that the cost of acquiring a new customer is five times the cost of retaining an existing customer and it has also been noted that one percent decrease in customer satisfaction results in a five percent decrease in investment return (Nouri \& Fatahi, 2011).

\section{Customer Definition:}

\section{Research literature:}

The customer is the person whom the organization wants to influence his or her behavior with the values they create (Hobson et al., 2002). Over the past decade, there has been a radical shift in the concept of business in the light of new managerial approaches where there is no customer-based approach and the fact is that the customer 
today is not paying for our product, but also, what he or she is asking for is the value that comes from the goods receiving or their considerable services. Customer satisfaction and loyalty are against what the producer of a product and services receives for its product and the amount of money received is merely an indicator to shows the extent of customers' trust (Ranjbarian et al., 2002). In another definition of customer, it is a group of natural or legal persons who buy certain goods and services to meet their needs (Maghsoudi \& Jamshidi, 2003). In other words, the wide range of people who interact with the organization and impact survival and profitability and they can be influenced, can be considered in the range of the customers of that organization.

\section{Customer Satisfaction Definition:}

According to surveys, the concepts of satisfaction and measurement were first expressed by "Oliver" in 1997. He described satisfaction as the enjoyment or gracious of past experiences of buying a product or service. Over the past four decades, satisfaction has become one of the most important conceptual issues as well as practical ones for marketers and customer researchers (Jamal, 2004). On the other hand, theorists are constantly looking for new ways and models to gain useful information about customer satisfaction; however, there is no simple definition of satisfaction that is generally accepted by all about the related literature on the subject (Melina et al., 2007), But the definition of customer satisfaction accepted by many experts is that customer satisfaction is the result of a prepurchase comparison of expected performance with actual perceived performance and the cost which is paid (Birley \& Et al., 2004).

The following relationship can be used to measure customer satisfaction:

Customer satisfaction $=$ Customer perception of quality - Customer expectations

Therefore, each of these definitions addresses this concept from a specific perspective. A set of definitions for customer satisfaction presented by theorists are shown in Table 1 .

Table 1 - Definitions of customer satisfaction from the perspective of some researchers

\begin{tabular}{|c|c|c|}
\hline Definition & Year & researcher \\
\hline $\begin{array}{l}\text { Customer satisfaction is the result of the customer's perception of a } \\
\text { transaction or value relationship such that the price is equal to the ratio of } \\
\text { the quality of service rendered to the price and cost of the customer. }\end{array}$ & 1996 & $\begin{array}{l}\text { Blanchard and } \\
\text { Galloway }\end{array}$ \\
\hline $\begin{array}{l}\text { Customer satisfaction means that they are satisfied with the way they } \\
\text { handle and deliver services to the organization and the organization has } \\
\text { been successful in attracting and retaining customers. These satisfied } \\
\text { customers expect the higher quality of service they receive, as the more } \\
\text { time and money they spend for the organization. }\end{array}$ & 1999 & Dinhalstide \\
\hline $\begin{array}{l}\text { A customer's feeling or attitude about a product or service is defined after } \\
\text { using it. The two researchers argue that customer satisfaction is the main } \\
\text { result of marketing activity that acts as a link between different stages of } \\
\text { consumer buying behavior .Or the service after using it. The two } \\
\text { researchers argue that customer satisfaction is the main result of } \\
\text { marketing activity that acts as a link between different stages of consumer } \\
\text { buying behavior. }\end{array}$ & 2002 & Jamal and Naser \\
\hline $\begin{array}{l}\text { Customer satisfaction is a result that comes from comparing pre-purchase } \\
\text { customer's expected performance with actual perceived performance and } \\
\text { the cost which is paid. }\end{array}$ & 2004 & Berli et al. \\
\hline $\begin{array}{l}\text { Customer satisfaction is the customer's ultimate response to the } \\
\text { consumption experience, which can be logical or emotional. }\end{array}$ & 2006 & Elronio \\
\hline $\begin{array}{l}\text { Satisfaction is a positive feeling which is created in a person after using } \\
\text { the goods or receiving the service; } \\
\text { The desired feeling arises from the conflict between customer } \\
\text { expectations and supplier performance. }\end{array}$ & 2008 & Saha and Zhao \\
\hline $\begin{array}{l}\text { Customer satisfaction is the result of a combination of cognitive } \\
\text { dimensions (beliefs about products and services) and emotional } \\
\text { dimensions (feelings about products and services). }\end{array}$ & 2009 & $\begin{array}{l}\text { Al-Esa and AL- } \\
\text { Mahmood }\end{array}$ \\
\hline $\begin{array}{l}\text { The emotional response to a particular purchase that results from } \\
\text { comparing the outcome of the purchase to some of the standards specified } \\
\text { before purchase. }\end{array}$ & 2010 & Kaliberg ang Rajesk \\
\hline The judgment that is made during consuming a product or service. & 2011 & Fin \\
\hline
\end{tabular}


A review of the literature on customer satisfaction reveals that scholars and researchers in the social sciences and psychologists have made numerous definitions of customer satisfaction over the past 30 years, that most of them overlap, but essentially present three common principles:

1- Customer satisfaction is a sensational - emotional reaction or a state of mutual and cognitive understanding.

2- Customer satisfaction is a response to focusing specifically on customer expectations of products (goods and services) and examining the customer experience after using these products.

3- Customer satisfaction is the reaction that occurs over a period of time. For example after the first election or based on repeated and accumulated experiences.

In general, satisfaction in marketing articles is defined as follows (Fiskawa, 2004):

- To satisfy the customer needs and desires

- Satisfaction as a joy

- Customer evaluation of goods or products quality

- The customer general approach to service Provider

However, all of the definitions agree that the concept of satisfaction implies the essential presence of the purpose that customers want to achieve. According to Hamburg et al. (2006), previous research has shown that both cognition, perception, and influence significantly predict satisfaction judgments.

\section{Concept of e-banking:}

With the increasing development of technology and industrialization of countries, bank managers are trying to increase the modern banking services, which distinguishes them from other competitors and has a special advantage in attracting customer deposits and marketing (Faraji, 2011).

Electronic banking can be introduced as the use of advanced networking and telecommunication technology to transfer money into the banking system. In fact, e-banking means optimizing the integration of all activities of a bank through the use of modern information technology, based on the banking process in accordance with the organizational structure of the banks, which provides all the services required by customers (Venus et al., 2002). Electronic banking is also referred to as providing customers with access to banking services through the use of secure intermediaries without physical presence (Kohzadi, 2003). Another definition of e-banking is to provide facilities to increase the speed and efficiency of the bank in providing banking services at any customer's desired location and providing customers with hardware and software facilities that enables them to perform their desired banking operations 24 hours per day, without the need for physical presence through secure and diverse communication channels.

\section{Maskan Bank History:}

Maskan Bank started its activities on January 15, 1939 with the establishment of mortgage bank of Iran as a specialized bank for housing and building with initial capital of 200 million Rials with the partnership of ministry of finance and Melli Bank of Iran. The Maskan bank activities, was forming the banking subjects related to housing issue. Paying facilities against the mortgage of immovable properties, with the purpose of purchasing, constructing, completing, repairing, and lending to construction companies had involved a major part of the activities. After the 1979 Revolution, Maskan Bank in 1979 according to the legal law of Banks managing issues approved 07/06/1979 by Islamic Revolutionary Council formed from merging of Iran mortgage Banks, building, investment banking company of Iran banks and other saving Companies and Korosh, Ekbatan, Pasargad house loans in Tehran and in other cities saving companies and house loan of Mashhad, Tabriz, Shiraz, Isfahan, Ahvaz, Gilan, Hamedan, Kermanshah, Mazandaran, Gorgan, Semnan and Abadan. Maskan Bank With its extensive network across the country as an accredited business organization, in addition to producing residential units, is active in donating facilities and services in housing part including bailment facilities, rental on condition of a lease for preparing a clinic, office work and medical equipment purchase, opening current accounts, issuance of all types of guarantees, remittances, check-fax services, foreign exchange and L / C and all types of electronic services that operate within the framework of the laws of the Islamic Republic of Iran.

According to the bank's statute, the bank's capital is 30,735,134,000,000 Rials and has 1272 branches throughout the country.

\section{Getting familiar with Kano model:}

In previous times, customer satisfaction was focused on one-dimensional structure, this means that the higher the quality of the product received by the customer, the more the customer satisfaction will increase, and vice versa. But it was not considered that meeting the needs of a particular product to a large extent, does not necessarily entail increased customer satisfaction. On the other hand, the type and size of customer needs can also influence the quality of the received product and consequently its satisfaction. In 1984, Professor Noriochi Kano and his 
colleagues introduced a model called Kano Customer Satisfaction Model, which is able to distinguish three types of product needs that affect customer satisfaction in different ways.

In this model, the service or product characteristics are divided into three basic categories such as: functional, and motivational, depending on how they are able to satisfy customer needs. And all three types of need are shown in a two-dimensional graph (Kano et al., 1984). Figure 1 illustrates the Kano model.

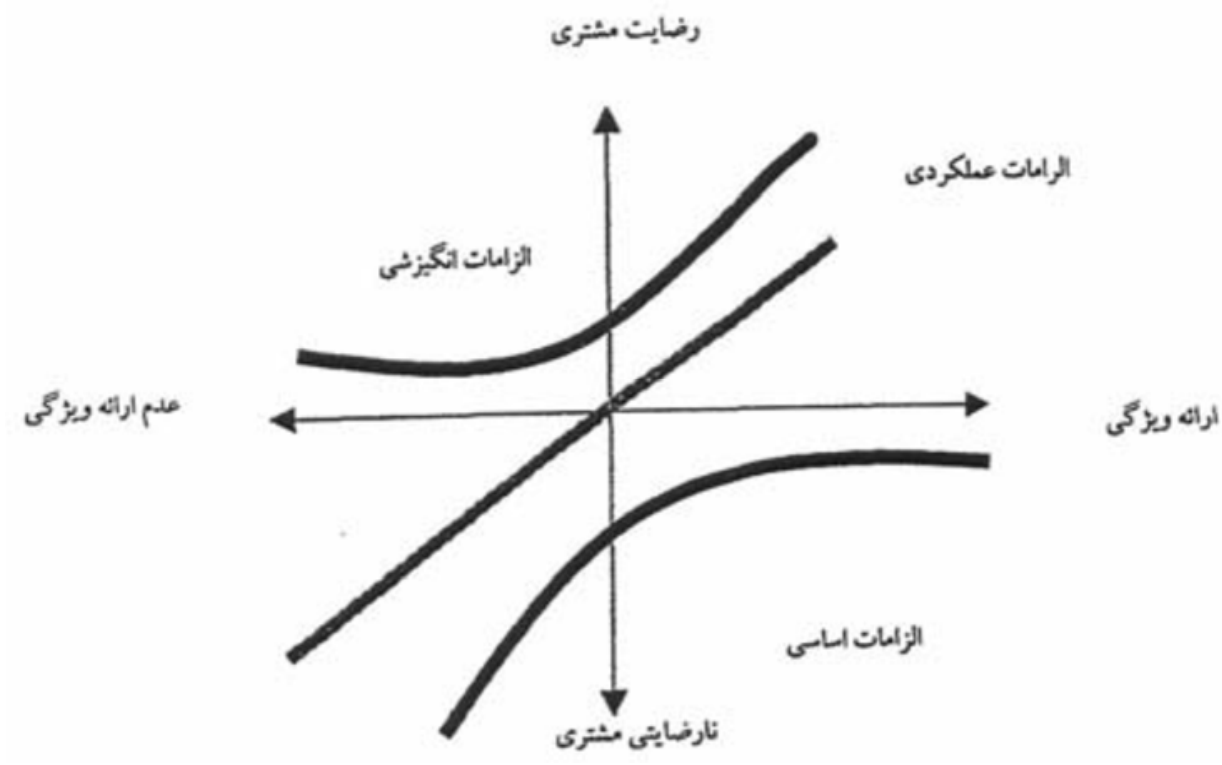

Figure 1: Kano model

Source: (Berger et al., 1993, p. 3)

The vertical axis, shows the level of satisfaction or customer happiness and the horizontal axis, indicates the amount of the presentation of the expected quality requirement of the customer. The highest and lowest point on the vertical axis of the graph indicates the customer satisfaction and customer dissatisfaction, respectively. Vertical and horizontal intersection indicates where the customer is in a state of imbalance mode in terms of satisfaction and dissatisfaction. The right side of the horizontal axis indicates where the expected quality requirement is fully presented and the left side of the horizontal axis is a product delivery point that does not have the expected quality properties and the quality requirement is not considered in any product or service (Rezaei et al., 2005).

\section{Basic requirements:}

These requirements are related to the features that must be present in a product and if not satisfied, the customer will be greatly dissatisfied. On the other hand, if these needs are in line with customer demands, their fulfillment will not increase customer satisfaction. Required needs are essential features of a product and their completion will ultimately lead to a dissatisfied phrase. This set of features is required to enter the market.

\section{Functional Requirements:}

Requirements are those that bring customer satisfaction as much as their level of satisfaction. That is, the more the need is met, the more customer satisfaction is provided, and vice versa. One-dimensional needs are usually explicitly demanded by the customer. These features make it possible to stay in the market.

\section{Motivational Requirements:}

These requirements are those product features that have a greater impact on customer satisfaction and dramatically increase customer satisfaction. Motivational needs are never explicitly stated or expected by the customer. Fully meeting these needs will increase customer satisfaction. Observing these group of features makes the company a market leader.

\section{Internal background:}

\section{Research Background:}

Hemmati (2018) investigated the impact of the quality of e-banking services on the extent of customer satisfaction with an emphasis on the role of customer satisfaction mediator in Eghtesede Novin Bank. In this study, the effect of factors such as reliability and assurance, responsiveness, empathy on the problem, etc. was performed on increasing customer satisfaction.

In another study, Spergham (2018) attempted to identify and classify the components of service quality in ebanking and its impact on customer satisfaction of Shahr Bank using the Kano model. The results showed that the 
components of content availability, ease of use, security, website design and physical facilities, reliability and responsiveness play an important role in shaping and enhancing the customer satisfaction.

In another study, Zand (2018) examined the impact of e-banking on customer satisfaction in Mellat Bank. The most important finding of this study showed that e-banking has a positive and significant effect on customer satisfaction.

\section{External background:}

In a study conducted by Bichang et al (Bichanga walter okibo and ali yattani wario, 2014) with the content of the effect of e-banking on customer growth in Kenyan banks, the results showed that e-banking leads to more customer growth and satisfaction. So this study recommends that banks should take advantage of e-banking as a competitive advantage.

Al-Haliq et al (Al-Haliq, 2016) conducted a study to investigate the level of customer satisfaction from e-banking services in the Saudi banking sector. In this research, descriptive and analytical method is used and basic data are collected through scaling survey. The results show that Saudi banks have achieved significant customer satisfaction by improving their e-services, facilitating e-transactions, improving processing performance and enhancing e-service specifications. In addition, they have gained effective communication with their customers as well as the speed of applications. However, there is a lack of awareness and guidance from customers about the electronic banking system. The results of this study lead to some recommendations for improving the electronic services provided by Saudi banks to increase customer satisfaction. Joshi and Saxena (Joshi and Saxena, 2018) conducted studies to assess the extent of satisfaction with internet banking services. The main reason for this study is to analyze the purpose of using internet banking, the reasons for choosing internet banking and the reasons for not choosing online banking. The results showed that people are highly satisfied with internet banking. The results also show that the main reason for using internet banking is the ease of users when conducting banking transactions and the only fear that users have is the issue of security in online banking.

\section{Goals and hypotheses of the research:}

Goals:

1- Investigating the obtained satisfaction with using electronic services

2- Investigating the factors that have the greatest impact on customer satisfaction

3- Investigating the factors that have the least impact on customer satisfaction

4- Classification related to factors affecting the extent of obtained satisfaction with the use of electronic services

\section{Hypothesis:}

1- Providing e-banking services is effective on customers' satisfaction.

2- The motivational factors of e-banking services effect on customer satisfaction.

3- The key factors of e-banking services effect on customer satisfaction.

4- Performance factors of e-banking services effect customer satisfaction.

\section{Research method:}

\section{Research Type:}

The present study is a descriptive-survey in terms of purpose, nature and method of data collection, and descriptive-analytical from statistics point of view. The time domain of this research is the second half of the year 1977 and its locative domain is Mashhad Maskan Bank Branches.

\section{Statistical population, sampling method and sample size:}

The statistical population includes all clients of Mashhad Bank of Mashhad who use electronic services during the research period.

In this study, we surveyed the level of satisfaction with these services by using non-random sampling method among the clients who used electronic banking services of Maskan Bank during the research period. In order to determine the number of samples, the Cochran's relation is used in the form of formula 1if the total size of the population is not specified.

Formula 1: $n=\frac{Z^{2} S^{2}}{d^{2}}$

In the above equation $\mathrm{S}^{2}$ is the variance of the trait studied, $\mathrm{d}$ is the optimal probability accuracy and $\mathrm{n}$ is the total sample volume. Statistical formulas cannot be used to estimate sample size if we do not have the variance of the population or the percentage of error and probability of success or failure and Morgan's famous sampling table is used to determine the sample size. This table gives the maximum number of samples, and if we calculate the 
sample size using the Cochrane sample size formula, usually a smaller sample number will be obtained. In the Morgan table, for populations over 300,000 , the maximum sample size is 384 . Also, as the maximum sample size is needed to measure satisfaction with e-banking services, more questionnaires were distributed to obtain the results. This research is a field and library data gathering method and the information required for this research is provided in two ways:

\section{Method and tools of data collection:}

Library Method: In this way, the necessary information is gathered to study the theoretical foundations of the research subject through the study of books, articles and refer to specialized sites.

Field method: Questionnaire, interview and observation are common tools for measuring variables in field method. In this research, by designing and distributing the questionnaire to the target population, the desired information was collected.

\section{Questionnaire validity:}

Previous research has been used to determine the content validity of the questionnaire, as well as a number of experts and professors have been asked and questioned to assess the hypotheses to confirm the validity of the questionnaire.

\section{Questionnaire reliability:}

One of the methods for calculating reliability is Cronbach's alpha coefficient. In order to calculate that, the variance of the scores of each questionnaire and the variance of the whole test must be calculated at first and then calculate its coefficient using formula 2.

Formula 2: $\alpha=\frac{k}{k-1}\left(1-\frac{\sum_{i=1}^{k} S_{i}^{2}}{\sigma^{2}}\right)$

In these relationships:

$\mathrm{k}=$ the number of questions or items on the questionnaire

$\mathrm{S}_{\mathrm{i}}{ }^{2}=$ the variance of the question $\mathrm{i}$

$\sigma^{2}=$ Total variance of general questions

If the Cronbach's alpha coefficient is greater than 0.7 , the reliability of the scale is evaluated as appropriate. The results of the reliability of the questionnaire used in the research are presented in Table 2.

Table 2 - Questionnaire reliability results

\begin{tabular}{|c|c|}
\hline Cronbach's alpha & The number of questions \\
\hline 0.925 & 20 \\
\hline
\end{tabular}

As it can be seen in Table 2, the Cronbach's alpha in this questionnaire equals 0.9254 which is higher than 0.7 and its reliability is confirmed.

\section{Tools and method of data analysis:}

Analysis of data collected were performed by SPSS software using descriptive statistics (graphs and statistics of frequency distribution) and inferential statistics (t-test, Kolmogorov-Smirnov goodness-of-fit test, One-sample Willcoxon test, Friedman test and other appropriate tests.

\section{Findings:}

\section{Population characteristics of the research sample:}

Gender: $70.2 \%$ of the population is men and $29.8 \%$ women.

Marital status: $78.8 \%$ of the population are married and $22.2 \%$ are single.

$12.7 \%$ of customers age who surveyed in this study were between $18-24$ years, $34.3 \%$ between $25-34$ years, $33.2 \%$ between $44-35$ years, $14 \%$ between $54-45$ years, $5.1 \%$ between $64-55$ years and $0.7 \%$ were over 65 years.

Educational degree of $4.3 \%$ of people is lower than diploma, $23.8 \%$ diploma, $19.2 \%$ high diploma, $39 \%$ a bachelor of degree, $12.7 \%$ master of degree, and $1 \%$ hold a Ph.D. degree or higher.

Amount of Bank Services usage: $9.6 \%$ of people used bank services 1-5 times a year, $7.8 \%$ of people $6-10$ times a year, $14.2 \%$ of people $11-20$ times a year and $68.4 \%$ of them used bank services more than 20 times a year. 
Electronic services used by customers: $18.7 \%$ of people mostly use internet bank, $34.5 \%$ of people mostly use ATM, $10.3 \%$ of people mostly use web kiosk, $16.5 \%$ of people mostly use mobile bank, $14.7 \%$ of people mostly use sale terminals and $5.3 \%$ of people mostly use telephone bank.

\section{Kano Analysis:}

In this section, the frequency of answers to the questionnaire by customers about the extent of their satisfaction with the service or e-services index is used and prioritizing the extent of the effect of these indicators on customer satisfaction with Friedman test is investigated that results are shown in Table 3.

Table 3 - Frequency of answers to the questionnaire questions

\begin{tabular}{|c|c|c|c|c|c|c|c|c|c|}
\hline $\begin{array}{l}\text { The } \\
\text { number } \\
\text { of } \\
\text { priority }\end{array}$ & $\begin{array}{l}\text { Rating } \\
\text { average }\end{array}$ & Type & $\begin{array}{l}\text { Very } \\
\text { low }\end{array}$ & Low & Average & High & $\begin{array}{l}\text { Very } \\
\text { high }\end{array}$ & $\begin{array}{l}\text { The extent of customer } \\
\text { satisfaction with the } \\
\text { Electronic Service Index } \\
\text { used }\end{array}$ & Row \\
\hline 2 & 10.91 & Basic & 0.76 & 2.78 & 27.09 & 46.08 & 23.29 & $\begin{array}{l}\text { Easy to read and } \\
\text { understand (user friendly) }\end{array}$ & 1 \\
\hline 3 & 10.42 & Basic & 0.51 & 4.60 & 25.32 & 48.59 & 20.97 & Privacy & 2 \\
\hline 6 & 9.75 & Performance & 2.02 & 6.57 & 29.55 & 45.45 & 16.41 & $\begin{array}{l}\text { User Response Time After } \\
\text { Request (Time Saving) }\end{array}$ & 3 \\
\hline 4 & 9.95 & Basic & 1.79 & 6.39 & 28.13 & 42.97 & 20.72 & Communication security & 4 \\
\hline 13 & 7.96 & Motivational & 4.58 & 11.45 & 36.64 & 33.84 & 13.49 & $\begin{array}{l}\text { Beauty (like web page } \\
\text { design or ATMs, etc.) }\end{array}$ & 5 \\
\hline 14 & 7.72 & Motivational & 4.36 & 14.10 & 34.36 & 37.18 & 10.00 & $\begin{array}{l}\text { The amount of creativity } \\
\text { and uniqueness }\end{array}$ & 6 \\
\hline 12 & 8.15 & Motivational & 1.28 & 10.74 & 38.87 & 37.34 & 11.76 & $\begin{array}{l}\text { Providing all or most of } \\
\text { the demands online }\end{array}$ & 7 \\
\hline 1 & 11.1 & Basic & 2.05 & 5.63 & 20.97 & 35.29 & 36.06 & $\begin{array}{l}\text { Being equal or better of e- } \\
\text { banking than traditional } \\
\text { banking }\end{array}$ & 8 \\
\hline 9 & 9.06 & Performance & 2.06 & 9.77 & 31.88 & 41.65 & 14.65 & $\begin{array}{l}\text { Quantity of provided } \\
\text { information }\end{array}$ & 9 \\
\hline 11 & 8.81 & Performance & 1.79 & 6.92 & 37.44 & 39.74 & 14.10 & $\begin{array}{l}\text { Quality of provided } \\
\text { information }\end{array}$ & 10 \\
\hline 8 & 9.09 & Performance & 1.53 & 8.44 & 34.02 & 40.66 & 15.35 & $\begin{array}{l}\text { The amount of } \\
\text { information transparency } \\
\text { and clarity }\end{array}$ & 11 \\
\hline 15 & 7.45 & Basic & 3.30 & 15.74 & 37.31 & 32.49 & 11.17 & $\begin{array}{l}\text { The amount of } \\
\text { relationship with other } \\
\text { banks }\end{array}$ & 12 \\
\hline 16 & 7.37 & Motivational & 5.00 & 16.05 & 36.32 & 32.89 & 9.74 & $\begin{array}{l}\text { Features different from } \\
\text { other banks }\end{array}$ & 13 \\
\hline 10 & 9.05 & Motivational & 1.30 & 7.25 & 32.90 & 46.63 & 11.92 & $\begin{array}{l}\text { The amount of being } \\
\text { online }\end{array}$ & 14 \\
\hline 17 & 6.9 & Basic & 7.55 & 17.97 & 31.51 & 33.33 & 9.64 & $\begin{array}{l}\text { Ability to correct errors by } \\
\text { user }\end{array}$ & 15 \\
\hline 7 & 9.4 & Performance & 2.86 & 9.61 & 27.53 & 39.74 & 20.26 & $\begin{array}{l}\text { Low cost of using } \\
\text { electronic services }\end{array}$ & 16 \\
\hline
\end{tabular}




\begin{tabular}{|c|c|c|c|c|c|c|c|l|c|}
\hline 5 & 9.9 & Motivational & 0.51 & 3.86 & 30.08 & 48.59 & 16.97 & $\begin{array}{l}\text { Number of acceptable } \\
\text { transactions }\end{array}$ & 17 \\
\hline-- & -- & nonsense & 2.53 & 9.09 & 34.85 & 36.62 & 16.92 & $\begin{array}{l}\text { Availability of all e- } \\
\text { Banking tools of Maskan } \\
\text { Bank }\end{array}$ & 18 \\
\hline-- & -- & nonsense & 2.78 & 12.41 & 35.19 & 35.19 & 14.43 & $\begin{array}{l}\text { Responding to all users' } \\
\text { needs }\end{array}$ & 19 \\
\hline-- & -- & nonsense & 3.28 & 6.06 & 28.03 & 43.43 & 19.19 & $\begin{array}{l}\text { The amount of the need } \\
\text { meet than the presence in } \\
\text { person in the bank }\end{array}$ & 20 \\
\hline
\end{tabular}

According to the results, the satisfaction rate of Maskan Bank customers toward being equal or better of e-banking than traditional banking rather than other services was higher and almost 71.36 percent of the customers who were present in the sample, were very much or much believed that e-banking was better than traditional banking or at the worst state, works like traditional banking. Also, the customers of Maskan bank less satisfied with the ability of users to correct errors than other electronic services. In other words, $42.63 \%$ of customers considered the possibility of user error correction in e-banking much or too much. On the other hand, according to the results of Friedman test, it can be seen that the characteristics of being equal or better of e-banking than traditional banking, which is one of the essential factors, has the greatest impact on customer satisfaction. Also, the feature of user errors correction which is one of the essential factors has the least effect on customer satisfaction. On the other hand, the main factor of e-banking services is more than other factors affecting on customer satisfaction. Also, the impact of e-banking service performance factor is more than the motivational factor of e-banking service on customer satisfaction which is shown in Table 4.

Table 4 - Friedman test to prioritize the extent of effectiveness of fundamental, performance, and motivational factors of e-banking services in customer satisfaction

\begin{tabular}{|c|c|c|}
\hline $\begin{array}{c}\text { Prioritizing based on the } \\
\text { Average of ranks }\end{array}$ & $\begin{array}{c}\text { Average of rank based } \\
\text { on Friedman test }\end{array}$ & Triple Dimensions \\
\hline 1 & 2.16 & $\begin{array}{c}\text { The essential factor of e- } \\
\text { banking services }\end{array}$ \\
\hline 3 & 1.72 & $\begin{array}{c}\text { The motivational factor of e- } \\
\text { banking services }\end{array}$ \\
\hline 2 & 2.11 & $\begin{array}{c}\text { Performance factor of } \\
\text { Electronic Banking Services }\end{array}$ \\
\hline
\end{tabular}

\section{The normality test of research variables:}

As shown in Table 5 and based on the Kolmogorov-Smirnov test results, the significance level of the test was less than 0.05 for the studied variables. Therefore, the null hypothesis of the Kolmogorov-Smirnov test based on the normality of data distribution of the variables is rejected. In other words, the variables of providing e-banking services, the effect of motivational factors of e-banking services, the impact of essential factors of e-banking services and the effect of e-banking services performance factors do not contain the normal distribution.

Table 5 - Kolmogorov-Smirnov test for normality of the research variables

\begin{tabular}{|c|c|l|}
\hline $\begin{array}{c}\text { the amount } \\
\text { of p- }\end{array}$ & $\begin{array}{c}\text { Z Kolmogorov } \\
\text { Smirnov test statistic }\end{array}$ & \multicolumn{1}{c|}{ Variable name } \\
\hline 0.000 & 2.134 & Providing electronic banking services \\
0.014 & 1.572 & The Impact of E-Banking Motivational Factor \\
0.007 & 1.673 & $\begin{array}{l}\text { The Influence of Essential Factors on E-Banking } \\
\text { Services } \\
\text { The Impact of E-Banking performance Factors }\end{array}$ \\
0.017 & 1.540 & \begin{tabular}{l} 
Ther \\
\hline
\end{tabular}
\end{tabular}




\section{Wilcoxon test:}

One-sample t-test and one-sample Wilcoxon test are used in mean comparison test, with respect to the normal or abnormal distribution of the variables under study, respectively. Therefore, according to the results of Wilcoxon test, it can be seen that the significance level of the test for the variables mentioned in Table 6 is less than 0.05. This means that variables are effective on customer satisfaction.

Table 6 - One-sample Wilcoxon test

\begin{tabular}{|c|c|c|}
\hline $\mathrm{p}$-the amount of & Test statistics & Variable name \\
\hline 0.00 & -11.613 & Providing e-banking services \\
\hline 0.00 & -11.873 & Motivational factors \\
\hline 0.00 & -14.420 & Fundamental factors \\
\hline 0.00 & -13.568 & Performance factors \\
\hline
\end{tabular}

\section{Discussion and conclusion:}

Customer needs classification provides the opportunity for bank managers to move faster and more intensely to meet customer needs and ultimately improve service quality by directing facilities to specific classes of the needs. In this research, Kano's powerful technique was used to categorize customer needs. In this study, all the stated hypotheses were confirmed. An important point that is evident in this study and other similar researches which conducted with the Kano model is that it is recommended that you meet all the essential requirements, and act on competitive toward performance requirements, and stay outstanding and stable by meeting the motivational requirements.

\section{Suggestions:}

1- Establishing a network for exchanging customer opinions within the bank branches and continually evaluating people's views on their satisfaction with the quality of provided services and trying to use critical and constructive feedback from clients and customers.

2- Selecting regional branch managers and authors based on their familiarity with banking system services as well as up-to-date electronic services.

3- Since the functional aspect is one of the most important factors from the customer's point of view, it is recommended to pay more attention to this dimension in order to satisfy customers and then their loyalty.

4- In order to reduce the gap between customer expectations and perceptions of motivational services, it is recommended that the Maskan bank should pay a special attention to incentive activities (e.g., Lottery or scoring for each transaction, etc.).

5- Customer getting familiar with website can be his first encounter. So it is very important to have a website that has the desired features.

6- The first and the last criteria of customer satisfaction is whether his expectations are met or not? Buyers of any product or service want to their products and services adopt with their expectations. It should never be forgotten that high quality advertising and smiling to customer alone, cannot deliver poor quality services. It should be kept in mind that the customer does not care that $98 \%$ of the service is flawless, but also he wants to get $100 \%$ and flawless service for the time he spends. So, firstly, it is recommended to determine what those expectations are. Then you need to set goals and focus the organization's human force on the areas that are most important for customers.

7- According to the process of privatization and the rise of presence of private banks in the field of banking services, this issue has brought various opportunities and threats to public banks. To this end, it is recommended that Maskan Bank, which is a governmental bank, maintain its competitiveness using modern management tools, to be able to use the most of the opportunities that emerge in the future and equip itself as much as possible against the potential threats.

8- Due to changes in customers' tastes and expectations that may arise over time, it is recommended that the process of identifying and understanding customer needs is periodically reviewed to provide greater customer benefit.

9- Considering that acceptance of e-banking has a direct relationship with its culture creation and adequate training, it is recommended that customers be informed in specific times to be trained for and branches are required to report, and even during those hours entertain customers and give them gifts, and of course one of the employees can only be assigned to train customers in the branches.

10- Due to the creation of a series of numerous and enduring advantages for the bank, it is recommended to form a special committee or council to consider how to create and launch future effective banking trends 
such as smart branches, selling financial services in branches (bank supermarket), banking, poor's banking, providing services for people without bank (without bank accounts), credit insurance, charitable banking, wholesale banking, electronic public relations, customer segmentation, etc.

\section{References:}

[1] Spergham, Behnam (2018). Identifying and categorizing service quality components in E-banking and its impact on maturity.

[2] Rezaei, Kamran \& Hooshyar, Mohammad (2005), QFD Customer Oriented Approach to Product Design and Improvement, Erotov Iranian Partnership.

[3] Ranjbarian, Bahram; Rashid Kaboli, Majid Yavari, Zahra; Haghighat, Asghar (2002). Customer Satisfaction with Quality of After Sales Service Case Study: Xerox Company in Isfahan Province. Journal of Business Research 25, 145-127.

[4] Zand, Fatemeh (2018). The Impact of Electronic Banking on Customer Satisfaction (Reflecting on the Customer Orientation of Managers of Alborz Province Mellat Bank).

[5] Seyed Javadin, Seyed Reza Yazdani, Shamsi (2005). Investigating Factors Affecting Customers' Intention to Use Internet Banking Services (Case Study of Saman Bank). Journal: Management of Knowledge Management 70, 62-45.

[6] Abbasi Nejad, Hossein; Mehrnoosh, Mina (2010). E-banking, Tehran: Post Publication.

[7] Fathiyan, Mohammad; Shafi'a, Mohammad Ali; Shahrastani, Maryam (2009). The Impact of E-Banking on Increasing Bank Customer Satisfaction (Case Study of National Bank of Iran)

[8] Faraji, Yousef (2011). Money, Currency and Banking. Commercial Publishing, Fifteenth Edition.

[9] Kahzadi, Nowruz (2003). Internet banking in Iran and the world. The first e-commerce conference.

[10] Maghsoudi, Mohammad Hossein-Jamshidi, Kamran (2003). The Relationship between Customer Satisfaction with Process Efficiency and Effectiveness, 4th Conference of Quality Managers.

[11] Nouri, Iraj; Fatahi, Kamil (2011). Journal: Management Research in Iran 15, 232-205.

[12] Venus, Referee and Fellows, March (2002). Iranian banking and the need for its development in Iran. Application: Management 67.

[13] Hapsson, Barry and Lou Gary, Jack et al. (2002). Service and Customer Service Management, Iran Nejad translation, Paris, Mehdi, Tehran: Modiran Publications.

[14] Hemmati, Parastoo (2018). The Impact of Electronic Banking Service Quality on Customer Reference with Emphasis on the Mediating Role of Customer Satisfaction.

[15] Al-Eisa A. S. and Alhemoud A. M.(2009), Using a multiple-attribute approach for measuring customer satisfaction with retail banking services in Kuwait, International Journal of Bank Marketing, Vol. 27, No. 4, PP. 294 - 314

[16] Avkiran, Necmi Kemal (1994), "Developing an instrument to measure customer service quality in branch banking", International Journal of Bank Marketing, Vol. 12, No. 6, pp. 10-18.

[17] Beerli, A., Martin J.D. \& Quintana A. (2004). A model of customer loyalty in the retail banking market. European Journal of Marketing, $38(1 / 2), 253-275$.

[18] Berger, C., Blauth, R., Boger, D., Bolster, C., Burchill, G., DuMouchel, W., Pouliot, F., Richter, R., Rubinoff, A., Shen, D., Timko, M., Walden, D. (1993). Kano's methods for understanding customer defined quality, In: Center for Quality Management Journal, Vol. 4, pp. 3-36.

[19] Bhavesh P. Joshi, Ashima Saxena (2018). International Journal of Trend in Scientific Research and Development (IJTSRD). Vol.4, No.1, Nov-Dec.

[20] Bichanga Walter Okibo, Ali Yattani Wario (2014), Effects of e-banking on growth of customer base in Kenyan banks.

[21] Culiberg, barbara. Rojsek, ica. (2010) " Identifying service quality dimension as anticedents to customer satisfaction in retail banking", economic and business review, vol. 12, No. 3, pp. 151-166.

[22] Diane Halstead. (1999) "The use of comparison standards in customer satisfaction research and Management", Journal of Marketing Theory and Practice.

[23] Fecikova, I. (2004) "A index method for measurement of customer satisfaction". TQM magazine, 16, 1, pp. 5766.

[24] Finn, Adam. (2011) "Investigating the non-linear effects of e-service quality dimensions on customer satisfaction", Journal of Retailing and Consumer Services, Vol. 18, pp. 27-37.

[25] Hani A. AlHaliq \& Ahmad A. AlMuhirat (2016). Asian Social Science; Vol. 12, No. 5.

[26] Homburg, C. Koschate, N. and Hoyer, W.D. (2006), "The role of cognition and affect in the formation of customer satisfaction: a dynamic perspective", Journal of Marketing, Vol. 70, July, pp. 21-31.

[27] Jamal, A. (2004). Retail banking and customer behaviour: a study of self-concept, satisfaction and technology usage. International Review of Retailing, Distribution and Consumer Research, 14 (3), 357-79.

[28] Jamal A. and Naser K.(2002), Customer satisfaction and retail banking: an assessment of some of the key antecedents of customer satisfaction in retail banking, International Journal of Bank marketing, Vol. 20, No. 4, PP. 146-160.

[29] Kano. N, N. Seraku, F. Takahashi and S. Tsuji, (April 1984), "Attractive quality and must- be quality", Hinshitsu, The Journal of the Japanese society for Quality control.

[30] Kotler,Philip.(2003),marketing management;11the Edition new jersey: prentice Hall .pp.52.

[31] Mishkin, F.S. (2001). "Financial policies and the prevention of financial crises in emerging market countries". NBER Working Papers, No. 8087.

[32] Molina, A and Martin-Consuegra, D and Esteban, A. (2007), "Relational benefits and customer satisfaction in retail banking", International Journal of Bank Marketing Vol. 25 No. 4, pp. 253-271.

[33] Oliver, R. L. (1997). Satisfaction: A behavioral perspective on the customer. New York, NY: Irwin/McGraw-Hill.

[34] Olorunniwo, F., Hsu, M. and Udo, G. (2006), "Service quality, customer satisfaction, and behavioral intentions in the service factory", The Journal of Service Marketing, Vol. 20 No. 1, pp. 59-73.

[35] Saha, P. and Zhao, Y. (2008), "Relationships between online service quality and customer satisfaction: a study in internet banking", available at: http://epubl.ltu.se/1404-5508/2005/083/LTU-SHU-Ex-05083-SE.pdf.

[36] Venkatesh, V., \& Davis, F. D. (2000). A theoretical extension of the technology acceptance model: Four longitudinal field studies. Management Science, 46, 186-204.

[37] www.bank-maskan.ir 